\title{
Effect of leaf biomass and phenological structure of the canopy on plot growth in a deciduous hardwood forest in northern Japan
}

\author{
Mika TAKIYA $^{\text {a* }}$, Kiyoshi UMEKI ${ }^{\mathrm{b}}$, Kihachiro KIKUZAWA ${ }^{\mathrm{c}}$, Yasutomo HIGASHIURA ${ }^{\mathrm{d}}$ \\ ${ }^{\text {a }}$ Hokkaido Forestry Research Institute Doto Branch Station, Nishi2, Shintoku, Hokkaido, 081-0038 Japan \\ ${ }^{\mathrm{b}}$ Graduate School of Science and Technology, Chiba University, Matsudo 648, Matsudo, Chiba, 271-8510 Japan \\ ${ }^{\mathrm{c}}$ Ishikawa Prefectural University, Nonoichi, Ishikawa, 921-8836, Japan \\ ${ }^{\mathrm{d}}$ School of Life Science, Tokyo University of Pharmacy and Life Science, Hachiohji, Tokyo, 192-0392 Japan
}

(Received 6 February 2006; accepted 15 June 2006)

\begin{abstract}
We monitored leaf biomass, seasonal changes in leaffall, and plot growth for 11 years post-thinning in a secondary deciduous hardwood stand dominated by Betula maximowicziana Regel in central Hokkaido, Japan. Annual leaf biomass was divided into two phenological amounts: leaves that fell from May to September (early foliage) and leaves that fell from October to November (late foliage). Annual leaf biomass and the ratio of late foliage to annual leaf biomass changed with stand development, thinning, and insect outbreaks. Multiple regression analysis revealed that the gross growth rate was positively dependent on both early and late foliage, whereas the effect of early foliage was stronger than that of late foliage. This result indicates that plot growth was determined by not only total leaf biomass, but also the phenological structure of the canopy. In assessing and controlling forest productivity, the phenological structure of the canopy should be considered.
\end{abstract}

disturbance / herbivorous insects / leaf biomass / plot growth / thinning

\begin{abstract}
Résumé - Effet de la biomasse foliaire et de la structure phénologique de la canopée sur la croissance d'un peuplement feuillu décidu dans le nord du Japon. Nous avons contrôlé la biomasse foliaire, les changements saisonniers des chutes de feuilles et la croissance d'un peuplement pendant 11 ans après une éclaircie dans une forêt feuillue secondaire dominée par Betula maximowicziana Regel, dans le nord du Japon. La biomasse foliaire annuelle a été divisée en deux parties phénologiques différentes : une partie tombée de mai à septembre et une autre correspondant aux feuilles tombées à partir d'octobre jusqu'en novembre. La biomasse foliaire annuelle et le rapport entre le feuillage en fin de saison et la biomasse foliaire annuelle ont changé en relation avec l'état de développement du peuplement, l'éclaircie et les interventions des insectes. L'analyse de régression multiple a révélé que le taux brut de croissance dépendait positivement tant du feuillage en début de saison que du feuillage en fin de saison de végétation, quoique l'effet du feuillage en début de saison a été plus fort que celui du feuillage en fin de saison. Ce résultat indique que le croissance du peuplement a été déterminée non seulement par la biomasse foliaire totale mais également par la structure phénologique de la canopée. Dans l'évaluation et le contrôle de la productivité des forêts, la structure phénologique de la canopée devrait être prise en compte.
\end{abstract}

perturbations / insectes herbivores / biomasse foliaire / croissance du peuplement / éclaircie

\section{INTRODUCTION}

Foliar or leaf biomass of a forest stand is the primary determinant of stand growth $[26,31,35]$ because foliage constitutes the photosynthetic organ of a tree. For example, as a young forest stand develops, leaf biomass and stand growth increase accordingly until the canopy closes [21]. Furthermore, because leaf biomass may be altered by disturbances that are followed by compensatory growth $[27,29]$, stand growth should be affected in turn.

The foliage of a forest stand is a heterogeneous assemblage of species, ages, photosynthetic traits, and other leaf characteristics. Therefore, the foliage has structure (e.g., age structure) that may change as the stand develops and undergoes disturbance. For example, an outbreak of herbivorous insects in the spring may alter the phenological structure of a canopy

*Corresponding author: takiya.mika@ pref.hokkaido.lg.jp by reducing the proportion of new leaves that develop during the outbreak. If leaves with different traits have differential contributions to biomass production, then changes in phenological structure may affect stand growth. Although this is an important factor in determining stand growth, it is poorly understood.

Here, we examined how the leaf biomass and phenological structure of the canopy, which varied with disturbance (thinning and/or insect herbivory) and stand development, determined plot growth in a secondary deciduous hardwood forest in northern Japan.

\section{MATERIALS AND METHODS}

\subsection{Study site and species}

The study was conducted in the experimental forest of the Hokkaido Forestry Research Institute in Bibai, central Hokkaido, 
Table I. Stem number and basal area in the study plots. Thinning was performed in 1984. Values (stem number and basal area just before and after thinning and thinning ratio) are shown for 1984 and 1995.

\begin{tabular}{|c|c|c|c|c|c|c|c|c|}
\hline \multirow[t]{3}{*}{ Plot } & \multicolumn{2}{|c|}{ Before thinning } & \multicolumn{2}{|c|}{ After thinning } & \multicolumn{2}{|c|}{ Thinning ratio } & \multicolumn{2}{|c|}{1995} \\
\hline & Stem number & BA & Stem number & BA & Stem number & BA & Stem number & BA \\
\hline & (Stems/ha) & $\left(\mathrm{m}^{2} / \mathrm{ha}\right)$ & (Stems/ha) & $\left(\mathrm{m}^{2} / \mathrm{ha}\right)$ & $\%$ & $\%$ & (Stems/ha) & $\left(\mathrm{m}^{2} / \mathrm{ha}\right)$ \\
\hline UT & 5293 & 15.8 & & & & & 3374 & 24.7 \\
\hline LT & 4020 & 15.5 & 3808 & 13.7 & 5.3 & 11.6 & 2657 & 22.8 \\
\hline HT & 3354 & 14.9 & 2616 & 8.9 & 22.0 & 40.7 & 2030 & 17.9 \\
\hline
\end{tabular}

BA: plot basal area, UT: unthinned plot, LT: lightly thinned plot, HT: heavily thinned plot.

northern Japan ( $43^{\circ} 15^{\prime} \mathrm{N}, 141^{\circ}$ 50' E; 200-210 m a.s.1.). The topography was gently sloping, and the basement geology consisted of alternating beds of sedimentary sandstone and mudstone of the Palaeogene system [4]. The mean annual precipitation and annual mean air temperature were $1134 \mathrm{~mm}$ and $7.1^{\circ} \mathrm{C}$, respectively.

The vegetation at the study site was deciduous hardwood forest dominated by Betula maximowicziana, with Sorbus commixta Hedl. and Tilia japonica Simonkai as subdominants. This was a secondary stand that regenerated naturally after a forest fire in 1960 . Betula maximowicziana, which sometimes dominates disturbed forest sites, is an early-successional species in forest communities in cool-temperate regions of Japan [25].

\subsection{Thinning}

Three 0.1-ha plots were established at the study site in 1983 and were thinned to varying stem densities in 1984 . One plot was lightly thinned (LT; stems composing $12 \%$ of the basal area removed), one was heavily thinned (HT; stems composing $41 \%$ of the basal area removed), and the final plot was left unthinned (UT; Tab. I). The mean $( \pm \mathrm{SD})$ diameter at breast height $(\mathrm{DBH}$; measured at a height of $1.3 \mathrm{~m}$ ) before thinning was $6.2 \pm 3.22 \mathrm{~cm}, 6.8 \pm 3.26 \mathrm{~cm}$, and 5.6 $\pm 2.51 \mathrm{~cm}$ in the LT, HT, and UT plots, respectively. Mean DBH after thinning was $6.0 \pm 3.11 \mathrm{~cm}$ and $6.0 \pm 2.82 \mathrm{~cm}$ in the LT and HT plots, respectively. Selection of trees for removal was determined on the basis of spacing, with no regard for tree size. Thus, thinning did not substantially alter mean DBH.

\subsection{Insect herbivory}

Two herbivorous insect outbreaks occurred during the course of the study: gypsy moth (Lymantria dispar L.) in 1987 and winter moth (Operophtera brumata L.) in 1993 (Higashiura, unpublished data). Gypsy moth larvae hatch in early May and pupate from late July to August $[5,6]$. These larvae feed on leaves of hardwoods and Japanese larch (Larix leptorepis Gordon or L. kaempferi Carr.; [19]). Winter moth larvae hatch in early spring following the leaf flush [13] and pupate during June. Because these two insects differ in phenology, especially in the timing of pupation, the damage caused by their feeding also differs; winter moths cause damage to early leaves, whereas gypsy moths cause damage to both early and late leaves.

\subsection{Estimation of plot growth}

Within each plot, all individuals $\geq 2 \mathrm{~cm}$ DBH were tagged and identified to species. DBH was measured to the nearest $1 \mathrm{~mm}$ and remeasured at 2-year intervals from 1983 to 1995 . Individuals that attained the minimum DBH (i.e., $2 \mathrm{~cm}$ ) during this period were also identified, tagged, and measured.

DBH was usually measured in early spring before the commencement of radial growth. However, some measurements were performed in July and September. In these cases, DBH in early spring was estimated from the DBH in July or September and from the phenological pattern of radial growth in B. maximowicziana [8] to calculate the 2-year-interval plot growth. This correction was necessary for the analysis of the correlation between plot growth and leaf biomass.

\subsection{Estimation of foliar mass}

Leaf biomass in forest stands is sometimes estimated using allometric relationships between leaf biomass and basal area or sapwood area $[1,23,36,37]$. However, this method is inappropriate when stands have been disturbed because disturbance may alter the relationship between leaf biomass and basal area or sapwood area [30]. In this case, leaf biomass is best estimated independently using litter traps [12] or measurement of light transmittance.

In 1985 , five regularly spaced $1-\mathrm{m}^{2}$ litter traps were placed in each plot. Litter was collected monthly. Litter collection usually began in June, but in some years it began in May or July. Differences in the start month of litter collection did not affect the estimation of litter biomass because litterfall from May to July was very small (see Results for details). Litter collection ended in October or November. The choice of final month was based on canopy observations; litter was only collected in November if a considerable quantity of leaves remained in the canopy in October. Litter measurements continued from 1985 to 1995.

Collected litter was oven-dried at $80{ }^{\circ} \mathrm{C}$ for $48 \mathrm{~h}$ and sorted into components, i.e., leaves, twigs, inflorescences, and other materials. We estimated leaffall per hectare by summing leaffall in the five traps and multiplying by a constant (2000, i.e., $\left.10000 \mathrm{~m}^{2} / 5 \mathrm{~m}^{2}\right)$ for each combination of plot and month. Annual leaf biomass was calculated by summing monthly leaffall.

To quantify the phenological pattern of leaffall and the corresponding phenological structure of the canopy, annual leaf biomass was divided into two components: leaves that fell from May to 
September (hereafter, LB1) and leaves that fell from October to November (hereafter, LB2). We set the LB1/LB2 boundary at the end of September because the greatest leaffall usually occurred in October, and most of the remainder fell between August and September (see Results for details).

We inferred a phenological canopy structure from LB1 and LB2 using a premise based on the timing of leaf emergence. Generally, leaves that open in early spring tend to fall earlier than leaves that open late [11], and this pattern was observed for the dominant species at our study site, B. maximowicziana; the date of emergence and the date of leaffall were positively correlated (Spearman rank correlation 0.926, $P<0.001, n=122$; K. Umeki, unpublished data). Therefore, LB1 approximates the amount of leaves that open early within a year, and LB2 approximates the amount of leaves that open late.

To express the relative importance of leaves that emerge late in the summer for annual leaf production, we calculated the ratio of LB2 to annual leaf biomass, i.e., LB2/(LB1 + LB2) (hereafter, relative LB2) We used relative LB2 to monitor long-term trends in the phenological structure of the stands, which changed with thinning and insect outbreaks.

We also inferred the morphological structure of the canopy from LB1 and LB2 using another premise based on the shoot morphology of Betula species. Betula trees generally have two types of shoots: long and short shoots [16]. Short shoots have very short stems with two or three early leaves that emerge in early spring; these maintain foliage with minimal investment in stem elongation. Long shoots have long stems with several late leaves that continue to emerge from spring until summer, and two or three early leaves at the shoot base; these function in crown expansion $[10,38,40]$. Therefore, relative LB2 should be correlated with the relative number of long shoots within a current-year shoot population. For example, a large relative LB2 indicates the presence of many long shoots within the canopy.

In addition to effects of thinning and insect outbreaks, relative LB2 may be affected by yearly climatic differences that shift the timing of leaffall. We examined whether yearly changes in climate conditions affected relative $\mathrm{LB} 2$ by regressing relative $\mathrm{LB} 2$ on mean temperature and precipitation during the growing season (May-October). We also examined whether strong winds resulted in early leaffall by regressing relative monthly leaffall (the ratio of monthly leaffall to annual leaffall) on maximum wind velocity for each month from June to October.

We could not statistically examine the effect of thinning or herbivory on stand characteristics because we had no plot replicates. Instead, we focused on the effect of leaf biomass and phenological structure, which were likely affected by disturbance (thinning and insect herbivory) and stand development, on plot growth rates.

\subsection{Data analysis}

Plot growth was calculated as gross growth, which is the increment in basal area (BA) produced by the radial growth of surviving individuals (i.e., survivor growth) + BA of individuals that attained the minimum DBH during a measurement period, i.e., ingrowth [2]. We evaluated the loss of BA as a result of mortality, and then calculated net growth (gross growth - mortality).

We used multiple regression analysis to examine the relationship between plot growth and variables describing plot structure at the beginning of the 2-year interval over which plot growth was evaluated. The response variables were gross growth and mortality; net growth

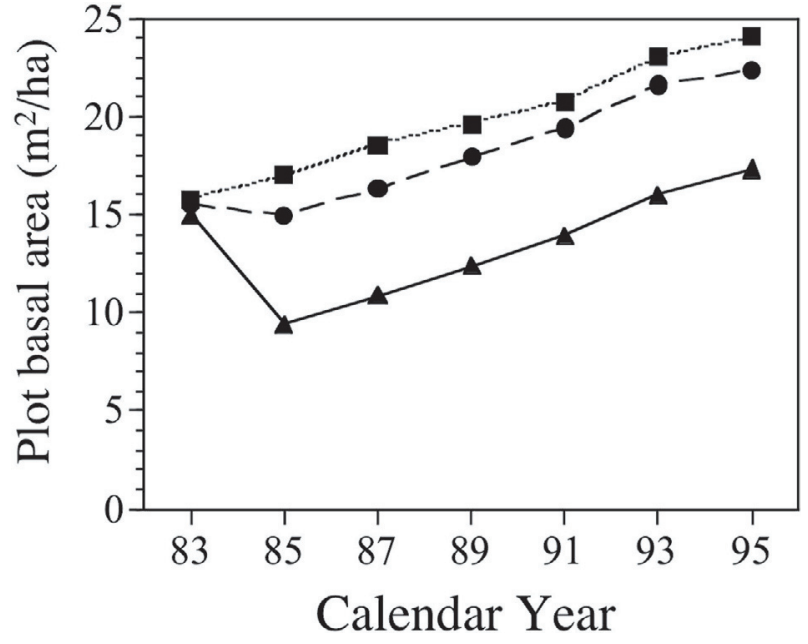

Figure 1. Changes in plot basal area (BA) from 1983 to 1995 at 2-year intervals. U Unthinned (UT); • lightly thinned (LT); $\Delta$ heavily thinned (HT).

was not included in the analysis because it is simply the difference between gross growth and mortality. The predictor variables were LB1, LB2, plot BA, and plot stem density. LB1 and LB2 were included as predictor variables because leaf biomass was expected to be closely related to plot productivity. Instead of annual leaf biomass (LB1 + LB2), LB1 and LB2 were considered separately because leaf productivity may differ between LB1 and LB2 $[14,15]$. BA was included as a predictor variable because it was expected to express maintenance costs [17]. Plot stem density was included in the regression models because stem density may affect stand growth [31].

Because plot growth was evaluated at 2-year intervals, annual total leaf biomass (LB1 and LB2) for 2 years was averaged to correspond to plot growth data. For example, the average LB1 calculated from LB1 in 1985 and LB1 in 1986 was related to plot growth from 1985 to 1987. Each regression included 15 data ( 3 plots x 52 -year intervals).

\section{RESULTS}

\subsection{Changes in basal area}

Thinning reduced the BA of the HT plot considerably and reduced the BA of the LT plot slightly between 1983 and 1985 (Fig. 1). After 1985 , BA increased in all plots.

\subsection{Plot growth}

In general, gross growth was in the order UT $>$ LT $>$ HT (Fig. 2a). During the first 2-year interval after thinning, differences among plots were large, but differences in growth decreased thereafter until 1991. The patterns of change in gross growth over time were similar among all three plots (Fig. 2a).

Mortality was also in the order UT $>$ LT $>$ HT (Fig. 2b). Yang [41] and Strong and Erdmann [33] also reported higher mortality in unthinned stands than in thinned stands. In UT, changes in mortality over time were opposite to those of gross growth. 

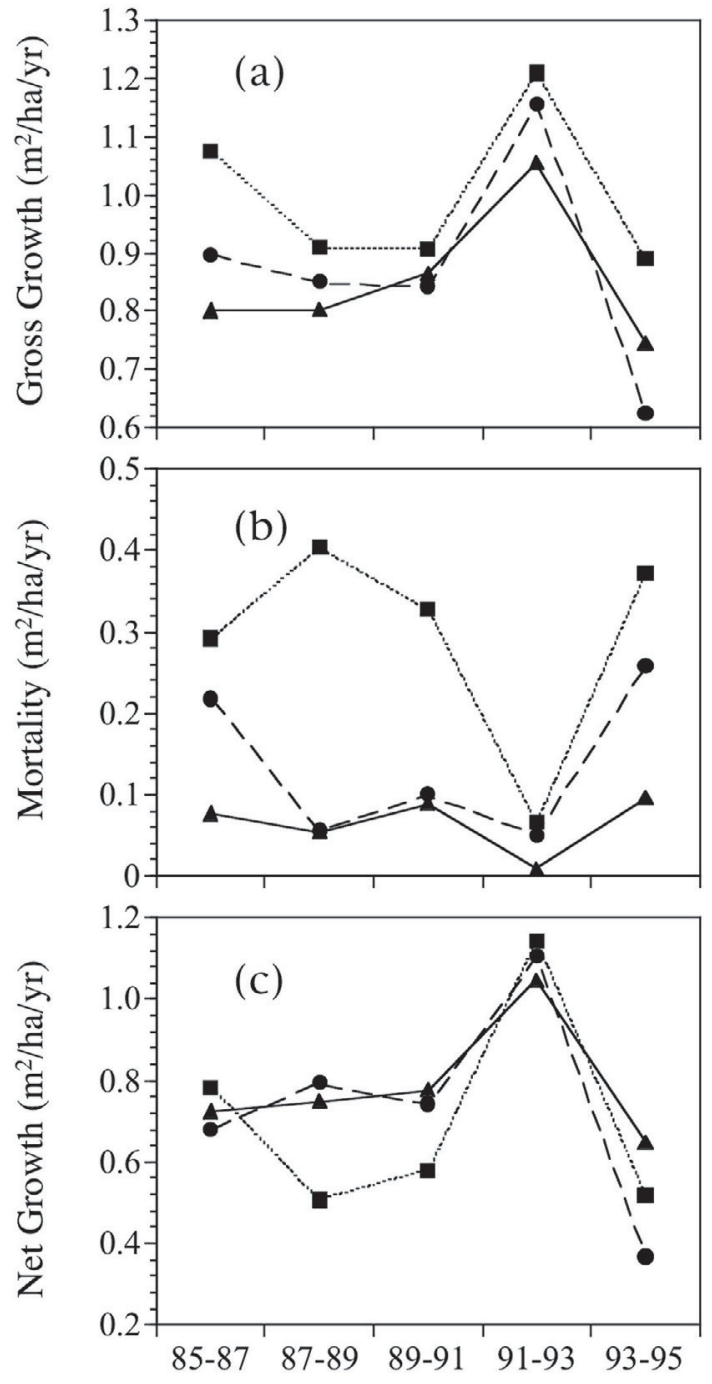

Calendar Year

Figure 2. Changes in (a) gross growth, (b) mortality, and (c) net growth from 1983 to 1985 . Unthinned (UT); • lightly thinned (LT); $\Delta$ heavily thinned (HT).

Net growth changed over time in a similar pattern among the three plots (Fig. 2c). We observed no clear differences among the plots in net growth (Fig. 2c) because the effects of gross growth and mortality cancelled each other.

\subsection{Changes in leaf biomass}

After thinning in 1985, we recorded large differences in leaf biomass among the plots (Fig. 3). In thinned plots (HT and LT), leaf biomass was reduced considerably by thinning in 1984. LT had $85.0 \%$ of the leaf biomass of UT, whereas HT had $55.3 \%$ of the leaf biomass of UT. This was similar to differences in BA among plots (LT: $88.4 \%$ of UT; HT: $59.3 \%$ of UT).

With the exception of 2 years (1987 and 1993), leaf biomass in UT was stable and ranged from 3.0 to $3.5 \mathrm{t} \mathrm{ha}^{-1}$. We observed two distinct decreases in leaf biomass in all plots in 1987 and 1993; these corresponded to outbreaks of gypsy moths and winter moths, respectively. Leaf biomass recovered almost completely within 2 years of each insect outbreak.

Despite the first decrease, leaf biomass in HT increased gradually after 1985 and reached a level similar to that in UT in 1992. Similarly, although leaf biomass in LT was reduced by thinning in 1985 , it quickly recovered to a level similar to that in UT in the following year, after which there appeared to be no differences in leaf biomass between LT and UT. Excluding reductions in leaf biomass by insect outbreaks, leaf biomass in UT was approximately $3 \mathrm{tha}^{-1}$. Leaf biomass in LT and HT increased over time and approached $3 \mathrm{t} \mathrm{ha}^{-1}$.

\subsection{Changes in the phenological canopy structure}

Seasonal changes in leaffall in four representative years are shown in Figure 4. 1985 and 1995 represent normal years (i.e., no insect outbreaks) during an early and late stage of stand development, respectively. In contrast, herbivorous insect outbreaks occurred in 1987 and 1993. In 1985, most leaves fell during or after October. In 1987, the peak of fallen leaves in October decreased compared to that observed in 1985. In the later stages of stand development (i.e., 1993 and 1995), leaffall increased during the months of June-September. In comparison to 1995,1993 had less leaffall during the period of June-September and a prominent peak of leaffall in October.

In each year, relative LB2 was larger in HT than in UT; generally, relative LB2 was intermediate in LT (Fig. 5). Differences among plots were small in 1985 (just after thinning) and in the last 2 years (1994 and 1995).

Relative LB2 decreased gradually over the long term, and we observed a distinct depression in 1987 and a distinct peak in 1993, which corresponded to insect outbreaks. The direction of change in relative LB2 depended on the phenology of the insects. The decrease in relative LB2 in 1987 corresponded to an outbreak of Gypsy moth, whose larvae consume both early and late leaves. The increase in relative LB2 in 1993 corresponded to an outbreak of winter moth, whose larvae consume only early leaves.

Neither mean temperature nor precipitation explained the variation in relative LB2 (temperature: $r^{2}=0.025, P=0.380, n=33$; precipitation: $r^{2}=0.037, P=0.281, n=33$ ). Monthly maximum wind velocity did not explain the variation in relative monthly leaffall $\left(r^{2}=0.000-0.009, P=0.176-0.995, n=33\right)$. Thus, annual fluctuations in climate did not appear to drive annual differences in relative LB2. Climatic differences also could not explain consistent differences among plots.

\subsection{Regression of plot growth with leaf biomass, phenological structure, and other plot structures}

Regression analysis revealed that gross growth depended positively on LB1 and LB2, and negatively on BA (Tab. II). The regression coefficient of LB1 was larger than that of LB2 $\left(F_{4,10}=3.87\right.$, $P=0.038$ ), suggesting that LB1 contributed to gross growth more than did LB2. Gross growth depended positively on plot stem density, although $P$ was slightly greater than 0.05 . Mortality depended negatively on LB1 and LB2, although the effect of LB2 was not significant and depended positively on plot stem density and BA $(P<0.05$; Tab. II). 


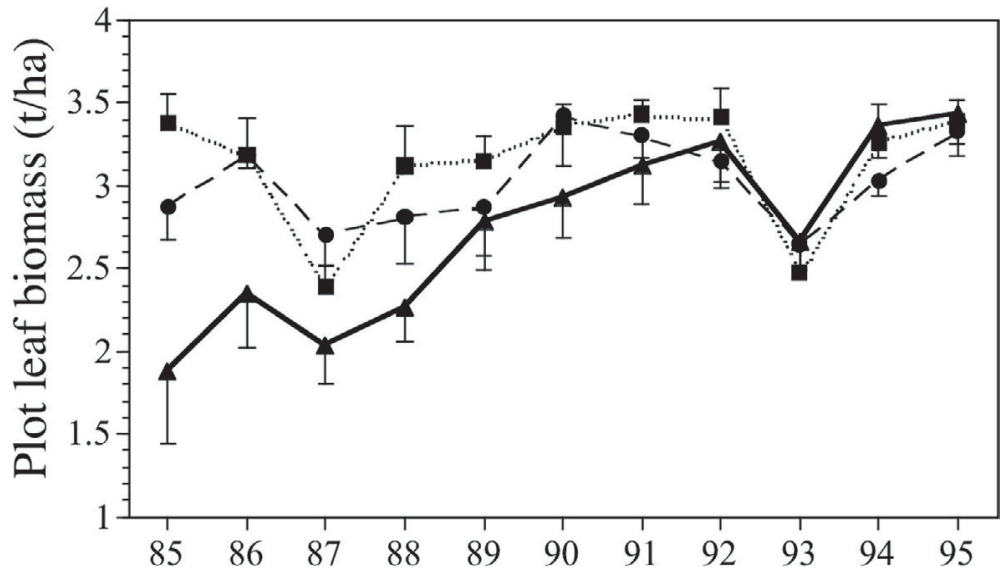

\section{Calendar Year}

Figure 3. Yearly changes in plot leaf biomass from 1985 to 1995. Vertical bars indicate SD. $\boldsymbol{\sim}$ Unthinned (UT); $\bullet$ lightly thinned (LT); $\boldsymbol{\Delta}$ heavily thinned (HT).

Table II. Results of multiple regression coefficients of gross growth $\left(\mathrm{m}^{2} \mathrm{ha}^{-1} \mathrm{yr}^{-1}\right)$ and mortality $\left(\mathrm{m}^{2} \mathrm{ha}^{-1} \mathrm{yr}^{-1}\right)$. Values in parentheses are $P$-values for the coefficients of determination $\left(r^{2}\right)$ and regression.

\begin{tabular}{lcccccccc}
\hline & \multirow{2}{*}{$r^{2}$} & Adjusted $r^{2}$ & Intercepts & & & \multicolumn{2}{c}{ Coefficients } \\
\cline { 5 - 8 } & & & & & Basal area $^{\mathrm{a}}$ & Stem density $^{\mathrm{b}}$ & LBI $^{\mathrm{c}}$ & LB2 $^{\mathrm{d}}$ \\
\hline Gross growth & 15 & $0.607(0.0377)$ & 0.45 & 0.441 & $-0.098(0.0368)$ & $0.0003(0.0518)$ & $1.170(0.0113)$ & $0.528(0.0295)$ \\
Mortality & 15 & $0.799(0.0016)$ & 0.719 & -0.148 & $0.050(0.0130)$ & $0.0002(0.0107)$ & $-0.661(0.0056)$ & $-0.2905)$ \\
\hline
\end{tabular}

LB1: biomass of leaves falling from May to September; LB2: biomass of leaves falling from October to November.

${ }^{a}$ Plot basal area measured at the beginning of the 2-year intervals $\left(\mathrm{m}^{2} \mathrm{ha}^{-1}\right) ;{ }^{\mathrm{b}}$ plot stem density measured at the beginning of the 2-year intervals (stems ha $\left.{ }^{-1}\right){ }^{\mathrm{c}}$ average (over 2 years) leaf biomass falling from May to September $\left(\mathrm{t} \mathrm{ha}{ }^{-1}\right){ }^{\mathrm{d}}$ average (over 2 years) leaf biomass falling from October to November $\left(\mathrm{t} \mathrm{ha}^{-1}\right)$

\section{DISCUSSION}

\subsection{Leaf biomass}

Sudden decreases in leaf biomass corresponded to disturbances (i.e., thinning and outbreaks of insect herbivores), followed by a certain period of leaf biomass recovery. Although leaf biomass increased following sudden decreases, it fluctuated around $3 \mathrm{tha}^{-1}$. This pattern of foliar biomass dynamics supported a previous finding that average leaf biomass in closed deciduous hardwood forest stands is approximately $3 \mathrm{t} \mathrm{ha}^{-1}$ irrespective of species composition, stand age, and stem density [34], and differed considerably from the BA pattern, which increased linearly. Changes in leaf biomass produced changes in plot growth.

\subsection{Foliage composition}

We found that the relative amount of late-falling foliage (relative LB2) changed as the stand developed, and was likely affected by both thinning and insect defoliation. The observed patterns in relative LB2 can be understood in concert with the canopy structure.

In early stand development, tree crowns spread vigorously by the elongation of long shoots $[7,22,39]$. Once the stand canopy has closed, however, horizontal elongation of long shoots becomes less important, and the maintenance of foliage by short shoots becomes increasingly important. Therefore, as the stand develops, the proportion of long shoots in the canopy decreases while that of short shoots increases. Thus, the long-term trend of decreasing relative LB2 (Fig. 5) reflects changes in foliage age structure that accompany stand development. However, even after canopy closure, vertical canopy expansion continues for a long period, so the relative LB2 cannot be very small.

Consistent differences in relative LB2 among plots are explained by differences in canopy structure. After a major disturbance that removes whole trees (thinning), the remaining tree crowns spread by elongation of long shoots until canopy gaps are closed. Therefore, the proportion of long shoots in the current-year shoot population increases in disturbed stands $[7,9,39]$. This explains the greater relative LB2 in HT than in UT. Once the canopy gaps in the thinned plots closed, the differences among plots decreased.

The effect of herbivorous insects on foliage age structure is more direct. Gypsy moth larvae eat leaves until pupation, which occurs in the summer. Larval growth and survival are reduced by the consumption of older leaves $[3,28]$. Therefore, the larvae prefer to eat young leaves that emerge relatively late in summer. Thus, the gypsy moth outbreak probably decreased relative LB2. In contrast, winter moth 

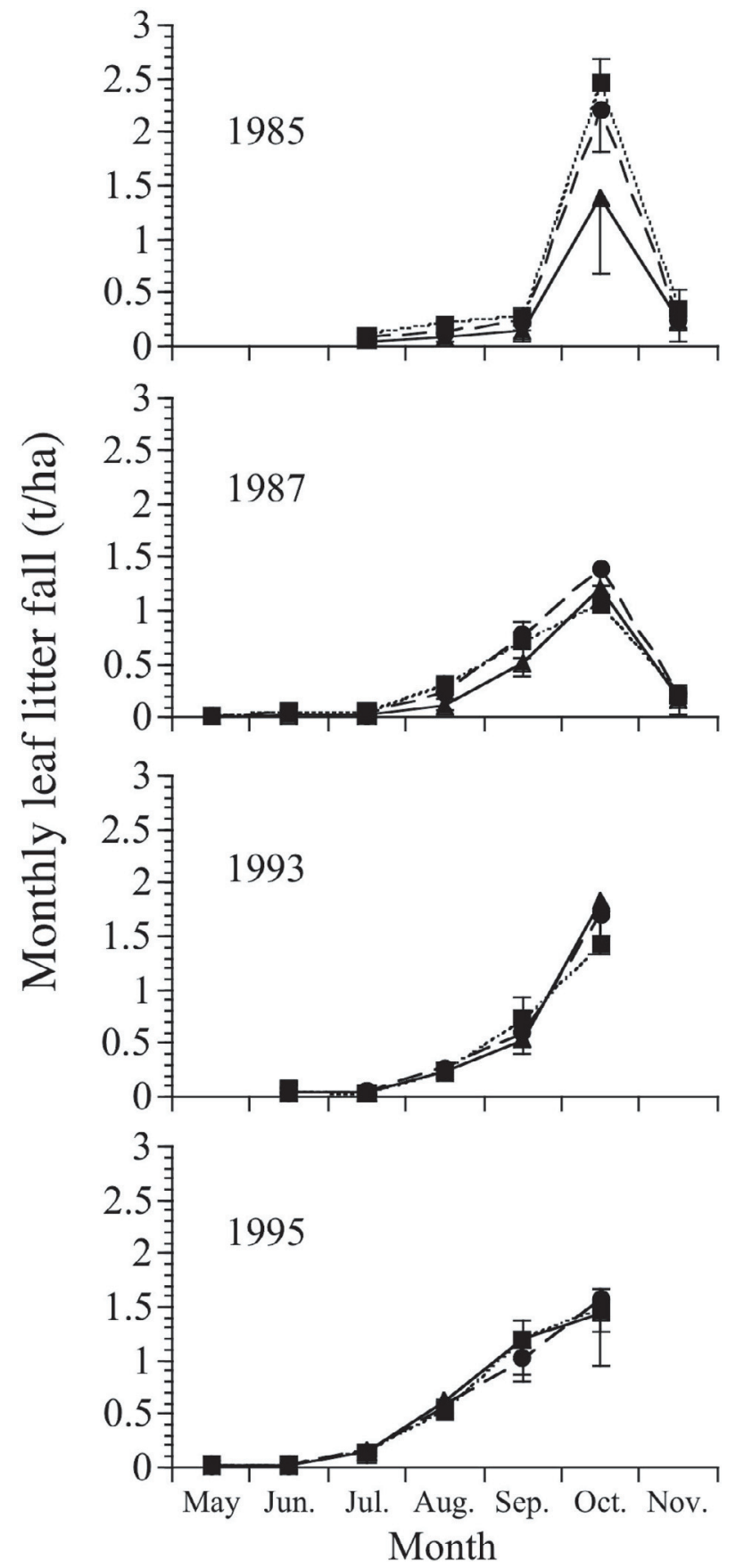

Figure 4. Monthly changes in plot leaffall in 1985, 1987, 1993, and

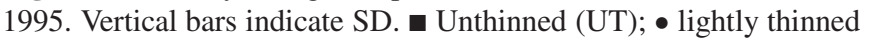
(LT); $\Delta$ heavily thinned (HT).

larvae pupate in June, so they only consume leaves that develop in spring [13]. Thus, the winter moth outbreak probably increased relative LB2. Both insects may have exerted strong effects on foliage age structure in the outbreak years; however, these effects were not sustained. Within 2 years of each outbreak, no lasting visible effects were evident. However, the effects of some insects on forest stands can be very severe or lasting, as observed in other cases (e.g., $[6,9,24])$.

\subsection{Dependence of gross growth on leaf biomass and stand structure}

As in previous studies, we found that plot growth (gross growth) depended positively on leaf biomass $[26,31,32,35]$. Increases and decreases in gross growth were consistent with changes in leaf biomass corresponding to thinning, insect herbivory, and stand recovery following disturbance.

The regression coefficient for LB1 was larger than that for LB2. This indicates that a certain amount of LB1 contributed more to gross growth than did the same quantity of LB2 because these variables had an identical unit and their regression coefficients indicated a rate of change in gross growth per $1 \mathrm{tha}^{-1}$ of LB1 or LB2. Because leaves produced early in the growing season fall earlier than leaves that are produced later, early leaves occur predominantly in LB1, rather than in LB2. Thus, the regression results indicated that early developing leaves contribute more to plot growth than do late-developing leaves. Koike and Sakagami [15] calculated the photosynthetic production by single leaves of different leaf orders from the shoot base to the tip and found that early developing leaves produce more carbohydrates than late-developing leaves in B. maximowicziana. The difference in carbohydrate production is mainly caused by differences in leaf life span $[14,15]$. Moreover, because the development of late leaves is accompanied by stem elongation that requires additional carbon investment, the net production of a late leaf is smaller than that of an early leaf, even if gross production is similar. Previous studies of the relationship between stand growth and leaf biomass assumed homogeneous foliage $[20,26,35]$, and the foliage quantity was expressed as a single amount. However, our results suggest that stand growth is affected by changes in foliage age structure because leaves of different ages contribute to stand growth differently.

The negative BA regression coefficient indicated that BA corresponds to energy consumption for respiration, whereas leaf biomass, which had positive regression coefficients, corresponds to production. Regression was able to separate the effects of leaf biomass and BA on gross growth because leaf biomass was estimated independently of BA, and changes in leaf biomass differed from those in $\mathrm{BA}$, corresponding to outbreaks of insect herbivores. In undisturbed stands, leaf biomass is often proportional to BA [23], so the effects of leaf biomass and BA on stand growth cannot be distinguished by regression even if stand growth is determined by production, which is proportional to leaf biomass, and maintenance costs, which are proportional to BA [18]. Le Goff et al. [17] also successfully estimated individual growth of Fraxinus excelsior using the difference between foliage photosynthesis and respiration from non-photosynthetic components (stem, branches, and roots).

Plot stem density was positively related to gross growth, although $P$ was slightly greater than 0.05 . This suggests the possibility that plots with higher stem density had greater gross growth than plots with lower stem density, with similar leaf biomass and BA. Long and Smith [20] found that the proportion of growth allocated to branches increased at the cost of trunk growth in sparse forest stands. The observed positive effect of plot stem density on gross growth may reflect this effect of dry matter allocation to branches and stems.

Acknowledgements: We thank members of the Silviculture Section, Hokkaido Forestry Research Institute, for help with field measurements and laboratory work. 


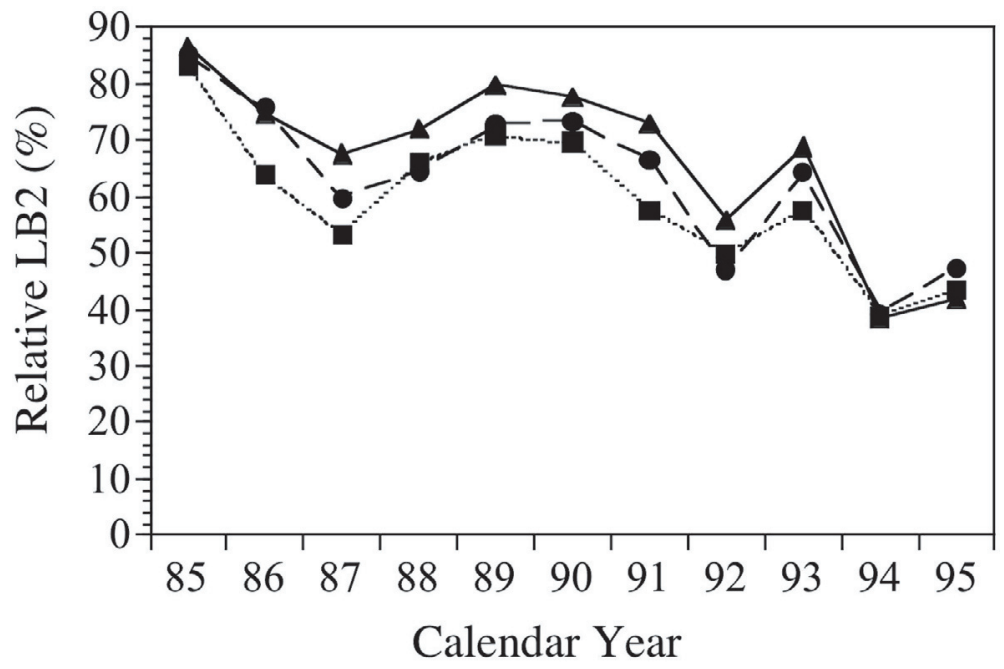

Figure 5. Yearly changes in the ratio of fallen leaf biomass in October and November to annual fallen leaf biomass (relative LB2). $\boldsymbol{\square}$ Unthinned (UT); • lightly thinned (LT); $\Delta$ heavily thinned (HT).

\section{REFERENCES}

[1] Bartelink H.H., Allometric relationships on biomass and needle area of Douglas-fir, For. Ecol. Manage. 86 (1996) 193-203.

[2] Beers T.W., Components of forest growth, J. For. 60 (1962) 245248.

[3] Elkinton J.S., Liebhold A.M., Population dynamics of gypsy moth in North America, Annu. Rev. Entomol. 35 (1990) 571-596.

[4] Geological survey of Japan, experimental text of the geological map of Japan, Iwamizawa, Hokkaido Development Agency, Sapporo, Japan, 1964 (in Japanese).

[5] Higashiura Y., Larval densities and a life-table for the gypsy moth, Lymantria dispar, estimated using the head-capsule collection method, Ecol. Entomol. 12 (1987) 25-30.

[6] Higashiura Y., Kamijo K., Mortality factors during the declining phase of a gypsy moth outbreak in a larch plantation in Hokkaido, Japan, Bull. Hokkaido For. Exp. Station 15 (1978) 9-16 (in Japanese).

[7] Jones M., Harper J.L., The influence of neighbours on the growth of trees II. The fate of buds on long and short shoots in Betula pendula, Proc. R. Soc. London, 1987, B232, 19-33.

[8] Kaji K., Hayashi Z., Suzuki T., The annual periodic growth rate of terminal elongation and stem diameter development in 5 deciduous broad-leaved tree species' saplings, Trans. Meeting in Hokkaido Branch of the Jap. For. Soc. 32 (1983) 210-212 (in Japanese).

[9] Karlsson P.S., Weih M., Long-term patterns of leaf, shoot and wood production after insect herbivory in the Mountain Birch, Funct. Ecol. 17 (2003) 841-850.

[10] Kikuzawa K., Leaf survival and evolution in Betulaceae, Ann. Bot. 50 (1982) 345-353.

[11] Kikuzawa K., Leaf survival of woody plants in deciduous broadleaved forests. 1. Tall trees, Can. J. Bot. 61 (1983) 2133-2139.

[12] Kikuzawa K., Asai T., Fukuchi M., Leaf-litter production in a plantation of Alnus inokumae, J. Ecol. 72 (1984) 993-999.

[13] Kikuzawa K., Asai T., Higashiura Y., Leaf production and the effect of defoliation by the larval population of the winter moth, Operophtera brumata L. in an alder (Alnus inokumae Murai et Kusaka) stand, Jpn. J. Ecol. 29 (1979) 111-120.

[14] Koike T., Time course of photosynthesis and leaf growth of deciduous broad-leaved trees, Trans. Jap. For. Soc. 97 (1986) 373-374 (in Japanese)
[15] Koike T., Sakagami Y., Comparison of the photosynthetic responses to temperature and light of Betula maximowicziana and Betula platyphylla var. japonica, Can. J. For. Res. 15 (1985) 631-635.

[16] Kozlowski T.T., Clausen J.J., Shoot growth characteristics of heterophyllous woody plants, Can. J. Bot. 44 (1966) 827-843.

[17] Le Goff N., Granier A., Ottorini J.M., Peiffer M., Biomass increment and carbon balance of ash (Fraxinus excelsior) trees in an experimental stand in northeastern France, Ann. For. Sci. 61 (2004) 577-588.

[18] Le Goff N., Ottorini J.M., Leaf development and stem growth of ash (Fraxinus excelsior) as affected by tree competitive status, J. Appl. Ecol. 33 (1996) 793-802.

[19] Liebhold A.M., Higashiura Y., Unno A., Forest type affects predation on gypsy moth (Lepidoptera: Lymantriidae) pupae in Japan, Environ. Entomol. 27 (1998) 858-862.

[20] Long J.N., Smith F.W., Determination of stemwood production in Pinus contorta var. latifolia forests: The influence of site quality and stand structure, J. Appl. Ecol. 27 (1990) 847-856.

[21] Long J.N., Smith F.W., Volume increment in Pinus contrata var. latifolia: the influence of stand development and crown dynamics, For. Ecol. Manage. 53 (1992) 53-64.

[22] Maillette L., Structural dynamics of silver birch. I. The fates of buds, J. Appl. Ecol. 19 (1982) 203-218.

[23] Mitchell J.E., Popovich S.J., Effectiveness of basal area for estimating canopy cover of ponderosa pine, For. Ecol. Manage. 95 (1997) 45-51.

[24] Mitchell R.G., Waring R.H., Pitman G.B., Thinning lodgepole pine increases tree vigor and resistance to mountain pine beetle, For. Sci. 29 (1983) 204-211.

[25] Mori T., The Betula Linn. (Birch), in: Katsuta M., Mori T., Yokoyama T. (Eds.), Seeds of woody plants in Japan: Angiospermae, Japan Forest Tree Breeding Association, Tokyo, Japan, 1998, pp. 39-47 (in Japanese).

[26] Oren R., Waring R.H., Stafford S.G., Barrett J.W., Twenty-four years of ponderosa pine growth in relation to canopy leaf area and understory competition, For. Sci. 33 (1987) 538-547.

[27] Piene H., MacLean D.A., Landry M., Spruce budworm defoliation and growth loss in young balsam fir: relationships between volume growth and foliage weight in spaced and unspaced, defoliated and protected stands, For. Ecol. Manage. 179 (2003) 37-53. 
[28] Raupp M.J., Werren J.H., Sadof C.S., Effects of short-term phenological changes in leaf suitability on the survivorship, growth, and development of gypsy moth (Lepidoptera: Lymantriidae) larvae, Environ. Entomol. 17 (1988) 316-319.

[29] Runkle J.R., Disturbance regimes in temperate forests, in: Pickett S.T.A., White P.S. (Eds.), The ecology of natural disturbance and patch dynamics, Academic Press, Orlando, Florida, 1985, pp. 17-33.

[30] Shibuya M., Yajima T., Kawai Y., Watanabe N., Nishikawa I., Recovering process and dynamics of the number of stems of major tree species in a deciduous broadleaved forest in 40 years after a large-scale disturbance by a typhoon, J. Jap. For. Soc. 79 (1997) 195-201 (in Japanese).

[31] Smith F.W., Long J.N., The influence of canopy architecture on stemwood production and growth efficiency of Pinus contorta var. latifolia, J. Appl. Ecol. 26 (1989) 681-691.

[32] Steinman J.R., MacLean D.A., Predicting effects of defoliation on spruce-fir stand development: a management-oriented growth and yield model, For. Ecol. Manage. 69 (1994) 283-298.

[33] Strong T.F., Erdmann G.G., Effects of residual stand density on growth and volume production in even-aged red maple stands, Can. J. For. Res. 30 (2000) 372-378.
[34] Tadaki Y., Hachiya K., The forest ecosystem and the matter production: Intelligible Instruction Manual Series of Forestry Research $\mathrm{n}^{\mathrm{o}}$ 29, Forest Development Technological Institute, Tokyo, Japan, 1968, pp. 9-12. (in Japanese).

[35] Waring R.H., Estimating forest growth and efficiency in relation to canopy leaf area. Adv. Ecol. Res. 13 (1983) 327-354.

[36] Waring R.H., Gholz H.L., Grier C.C., Plummer M.L., Evaluating stem conducting tissue as an estimator of leaf area in four woody angiosperms, Can. J. Bot. 55 (1977) 1474-1477.

[37] Whitehead D., The estimation of foliage area from sapwood basal area in Scots pine, Forestry, 51 (1978) 137-149.

[38] Yagi T., Morphology and biomass allocation of current-year shoots of ten tall tree species in cool temperate Japan, J. Plant. Res. 113 (2000) 171-183.

[39] Yagi T., Functional differentiation of modules in broad-leaved tree species, Jpn. J. Ecol. 50 (2000) 235-250 (in Japanese).

[40] Yagi T., Kikuzawa K., Patterns in size-related variations in currentyear shoot structure in eight deciduous tree species, J. Plant Res. 112 (1999) 343-352.

[41] Yang R.C., Foliage and stand growth responses of semimature lodgepole pine to thinning and fertilization, Can. J. For. Res. 28 (1998) 1794-1804. 